\title{
The Discussion of Theory and Practice on Decentralization and Service Delivery
}

\author{
Priyantha W. Mudalige (PhD Candidate) \\ Graduate School of International Relations, \\ International University of Japan, Niigata, Japan
}

Doi:10.19044/esj.2019.v15n14p115 URL:http://dx.doi.org/10.19044/esj.2019.v15n14p115

\begin{abstract}
In recent years, the responsibility of service delivery has strategically shifted from the central government to the most localised public sectors. Decentralization implies that a sub-national level government can choose between different measures and adapt service delivery to local circumstances or the characteristics of individual service recipients. Various governments around the world have started decentralization based on the principle of selfgovernance. It has many successes and has become a method of choice for people to get closer to goods and services. In addition, most governments have decided to use decentralization to empower the local population for political, economic, social, management, administration, and technology. As a result, local people can participate in the planning and management of development processes and decision-making. The specific objective of this paper is to discuss the relationship between decentralization and service delivery and is primarily based on literature review. Many governments have recognized the use of decentralization models based on their economic, political, cultural, and geographical factors, and decentralization could be understood as a process of expanding the role of sub-national governments. Every central government has to perform nationally-recognized functions. But sub-national level governments need to provide services and make decisions that are specific to their own affairs. Therefore, the decentralized structure plays a huge role in the administration and development of a country.
\end{abstract}

Keywords: Asymmetrical, Decentralization, Governance, Service delivery

\section{Introduction}

Many countries in the world have differences in population, wealth, natural resources, geographical diversity, as well as culture, language, history, ethnicity, and religion, within their borders. Consequently, such differences among these countries generate various goals to achieve. There is also the need 
for reasonably acceptable governance for each part of the country, which can deliver better service to every level of the government. Decentralization is the most popular mechanism in this context.

In 1989, there were sixty nine democratic countries, which grew to one hundred twenty-five by 2014. In 1989, 2.28 billion people lived in democratic countries, and by 2014, it has increased to 4.18 billion (Piccone, 2016, p. 2). Such drastic increases led to decentralization becoming widely recognized as an essential process for strengthening democratic practices in many countries around the world (Karmel, 2017, p. 1). Shah and Thompson (2004, p. 1) pointed out that decentralization has spread in the world as a silent revolution in public sector governance. Sub-national governments across the globe play critical roles in the delivery of basic public services and provide public infrastructure (Clos, 2015). Service delivery at the sub-national level has also assumed much importance in the mitigation of the wide variance in regional disparities. Decentralization influences in creating a conducive environment for sustainable good governance and efficient service delivery (Parr \& Ponzio, 2002 , p. 2). The legitimacy of the state rests on the service delivery institutions that meet citizens' demands (Girishankar, 1998, p. 1).

One factor that complicates decentralization is how layered government administration may be. Looking across the globe countries has many different sub-national government layers. Typically, those countries distribute administration over one, two, or three segments of the sub-national governments. Some of countries have highly complex layers of sub-national governments. For instance, China has four or five sub-national government structures (OECD, 2016, pp. 14-16). Table 1, illustrates the layers of the subnational governments. Since most sub-national governments are comprised of one, two or three layers. They are most often referred to as the municipal-level, intermediate-level, and regional level. The economic and political needs of the country determine the size and layers of sub-national governments. Service delivery is a crucial way for improving the capacity of the state to ensure the economic and social principles of sustainable growth, and the mechanism of decentralization is an essential channel to deliver services to the people at the sub-national level in a government. The purpose of this paper is to discuss the relationship between service delivery and decentralization. It particularly focuses on the nature of the concept of decentralization and this study was basically based on a review of the literature.

The rest of the article is organized into sub-sections as follows: section two offers a brief review of the literature. The definition and basic features of decentralization are presented in section three. The relationship between decentralization and the delivery of service is covered by section four. The final section has covered empirical findings and the conclusion in the article. 
Table: 1, Sub-national Government Layers

\begin{tabular}{|l|l|l|l|l|}
\hline \multicolumn{1}{|c|}{ Tiers } & $\begin{array}{l}\text { No. of } \\
\text { municipal- } \\
\text { level } \\
\text { governments }\end{array}$ & $\begin{array}{l}\text { No. of } \\
\text { Intermediate- } \\
\text { level } \\
\text { governments }\end{array}$ & $\begin{array}{l}\text { No. of state/ } \\
\text { regional-level } \\
\text { governments }\end{array}$ & $\begin{array}{l}\text { Total } \\
\text { number } \\
\text { of SNGs }\end{array}$ \\
\hline $\begin{array}{l}\text { Single-tiered SNG } \\
\text { countries }\end{array}$ & 5718 & 0 & 7 & 5725 \\
\hline $\begin{array}{l}\text { Two-tiered SNG } \\
\text { countries }\end{array}$ & 302843 & 102 & 1050 & 303995 \\
\hline $\begin{array}{l}\text { Three-tiered SNG } \\
\text { countries }\end{array}$ & 201187 & 11079 & 643 & 212909 \\
\hline Total & 509748 & 11181 & 1700 & 522629 \\
\hline
\end{tabular}

\section{Literature Review}

A considerable quantity of research literature is available on the relationship between decentralization and the delivery of services. In this regard, the aggregating findings are important for the future. According to Karmel (2017, p. 5), decentralization is initially pursued as an administrative reform process to enhance service delivery and economic efficiency, and decentralization has become widely considered as an essential process for strengthening democratic practice in countries. The extraordinary scope of the concept of decentralization is revealed by many objectives that it serves. Programmes are decentralised with the expectation that delays will be reduced and that administrators' indifference to satisfying the needs of their clientele will be overcome. It is thought that decentralization will improve government's responsiveness to the public and increase the quantity and quality of the services it provides (Rondinelli, Nellis, \& Cheema, 1983, p. 9).

To Tiebout (1956, pp. 419-420), decentralization means the distribution of resources, making decisions, improving public services and service delivery, and facilitating an exchange of information. Ekpo (2008, pp. 2-3) explained that improving service delivery at the sub-national and lower levels of government can effectively deliver services such as water, education, sanitation, and health. Also, at the lower levels of a government, politicians and civil servants are more aware of the needs of their community and will be more responsive to provide such services. Khaleghian (2003) viewed decentralization through the prism of childhood immunization in low and middle-income countries. He pointed out that decentralization has had a negative impact on middle-income countries when it has a positive effect on childhood immunization in low-income countries. Aslam and Yilmaz (2011) stated that the results of Pakistan's decentralization and service delivery reveal that the reforms of the decentralization process by the government have significantly increased through the provision of all services. Lewis (2016, pp. 815-817) studied the impact of local government expenditure on the delivery 
of service in Indonesia. This empirical examination revealed that district expenditure had a positive influence on access to education, health, and infrastructure services. According to Mclean and King (1999, p. 56), primary and secondary educational services should be fully decentralized, which should encourage resources under decentralization. Wagana, Iravo, Nzulwa, and Kihoro (2016a, pp. 312-313) have described the relationship of fiscal decentralization and service delivery in Kenya by using a descriptive survey design for the investigation. The research revealed a significant positive relationship between fiscal decentralization and service delivery.

Shen, Zhao, and Zou (2014, p. 137) attempted to explore the key issues and challenges in China's decentralized public service delivery and financing system and presented some important findings. It points out the necessity to promote local government responsibility for the provision of good public services. Khemani (2006) declared that local governments were a suitable mechanism for providing essential health services to the poor communities in Nigeria. Tshukudu (2014) emphasised the importance of providing an efficient service to decentralization, among which, the process of implementing decentralization should be optimum. Bardhan and Mookherjee (2006) pointed out that service delivery affects the nature of decentralization, and for a better service, both revenue and expenditure should be decentralized. Asfaw, Froherg, James, and Jutting (2007) examined how fiscal decentralization impacted India's infant mortality rate from 1990 to 1997. The random effect regression results indicated the importance of fiscal decentralization was statistically significant in reducing the infant mortality rate.

Faguet (2014) disclosed relationships between decentralization and policy-relevant outcomes such as education, health services, public investments, level of corruption, and national and subnational fiscal deficits. According to this study, decentralization does not allow local politicians to quit the responsibilities of their voters. Ghuman and Singh (2013) stated that the theory of decentralization suggests a high correlation between service delivery and payment and proposes that economic efficiency of local governments is enhanced, and the quality of service delivery is improved when citizens pay user charges for the services delivered.

Schneider (2003, p. 41) introduced several ways to analyse the concepts of decentralization: (1) subnational expenditure as a percentage of expenditure; (2) subnational income as a percentage of total income items; (3) the relative importance of tax as a percentage of subnational income; (4) the relative importance of transfers as a percentage of subnational income; (5) the existence municipal elections; and (6) the existence of state or provincial elections. The author pointed out that these variables can be used to measure political, administrative and fiscal decentralization. These variables may also be used to test the impact of decentralization on social outcomes. Uchimura 
and Kono (2012, pp. 113-116); Uchimura and Suzuki (2012, pp. 49-51) introduced two decentralization indicators, i.e., the local share of total fiscal expenditure and local share of total fiscal revenue. These indicators are intended to measure the impact of fiscal decentralization on service delivery. Ebel and Yilmaz (2002) revealed the ability to measure the sub-national share of the total government spending and revenue regarding fiscal decentralization, while Rao (1998, pp. 83-86) analysed the share of state governments in total expenditures of governments in India. The government has prioritised the decentralization mechanism to provide welfare services at the rural and sub-national levels. Abdur et al. (2017, p. 180) have discussed implications of fiscal decentralization on public service provision in Pakistan. The study was based on annual data from 1972 to 2009 (time series data) and Autoregressive Distributive Lag model for analysis, that has been used to estimate long-run coefficients. According to the findings of the study, longrun fiscal transfers significantly influence the infant mortality rate. Furthermore, vertical balance and fiscal transfers in the short-run have a significant impact on public service (health) provision.

\section{Definition}

Basically, the word decentralization contains the meanings of the Latin roots, with the general meaning being "away from the centre" (Meenakshisundaram, 1994, p. 11). This interpretation specifies the handingover of the central government's power to a lower level of the government. As Wollmann defines, decentralization is the transfer of powers and activities to the sub-national level and actors. They have political autonomy under their own right within the intergovernmental setup (Wollmann, 2007, p. 2). According to Work's definition, decentralization is the transfer of responsibility to the lower levels of the central government for planning and management. For this, the central government allocates and increases resources to the lower levels of the government (Work, 2002, p. 5). Also, Hossain (2005, p. 2) sees, decentralization as "the transfer of power and authority from the central government to regional or sub-national governments units according to the demand of the rural people". To Rondinelli (1981, p. 137) decentralization is the, "transfer of legal and political authority to plan, make decisions, and manage public functions from the central government and its agencies to field organisations of those agencies, subordinate units of government, semi-autonomous public corporations, area-wide or regional development authorities, functional authorities, autonomous local governments, or non-governmental organizations." This definition demonstrates the transfer of central government power to government institutions or semi-autonomous government and the private sector. It also covers both horizontal and pyramidal decentralization, including the regions 
and subordinate levels of the government (Herath, 2009, p. 159). Taken in aggregate, decentralization is safely defined as the transfer of specific functions and responsibilities of the central government to governmental and non-governmental agencies from various sizes and qualities.

\section{Objectives of Decentralization}

Many governments of the world use decentralization for various political, administrative, and economic purposes. Cheema and Rondinelli (1983, pp. 14-16) offer the best summery of those purposes: "Increase people's participation in local development, planning and management, coordinate administrative functions, political and administrative "penetration", creating social equity, more effective coordination, allowing local "experiments", lead to more flexible, innovative and creative administration, isolated or backward areas of development, integration of regional economies, macroeconomic stability, improve political stability, decentralizing public goods and services, participation planning, monitoring, and evaluation, delivery of goods and services, local level financial management and administrative efficiency, so on"

There are several motives for governments to decentralize. In Central and Eastern Europe and the former Soviet Union, it has become part of the political and economic transformation, while in Latin American countries it has contributed to the transition to democracy. In Ethiopia, Indonesia, Yugoslavia, Nigeria, Sri Lanka, and Philippines decentralization addressed ethnic or political conflicts. In Chile, Uganda, Cote D'Ivoire, decentralization aims to improve the provision of basic services. For the Czech Republic, Slovakia, Hungary and Poland, there was one of the prerequisites for access to the European Union. In Argentina, Brazil, Bolivia, Colombia, India, Pakistan, and the Philippines decentralization enhanced people's participation in government. In China, it aims to protect communist rule in a populous and diverse country. Meanwhile, in African countries, it is based on shifting of responsibility for unpopular adjustment programmes (Shah \& Thompson, 2004, p. 3) and (Ahmad, Devarajan, Khemani, \& Shah, 2005, p. 1). There is evidence to prove that decentralization expects to enhance the services of many governments based on multi-dimensional needs.

\section{Dimension of Decentralization}

There is no common consensus among the scholars on what constitute types of decentralization. Meenakshisundaram (1994, p. 11), for example, describes it as de-concentration, devolution, delegation, privatisation, and deregulation. Cheema and Rondinelli (1983, p. 18) have identified four main types of decentralization namely: (i) de-concentration, (ii) delegation to semiautonomous or parastatal agencies, (iii) devolution to local governments, and 
(iv) transfer of functions from public to non-governmental organizations. In the view of Mugabi (2005, p. 24) decentralization can be categorised into four sections. These sections include (i) deconcentration, (ii) delegation/delinking, (iii) devolution (of power), and (iv) divestment/ privatisation (of public functions).

Table 1: Forms and Dimensions of Decentralization

\begin{tabular}{|l|l|l|l|l|}
\hline $\begin{array}{l}\text { Forms and } \\
\text { Dimensions }\end{array}$ & Privatisation & Delegation & Deconcentration & Devolution \\
\hline Market & & & & \\
\hline Administrative & & & & \\
\hline Political & & & & \\
\hline Fiscal & & & & \\
\hline Asymmetric & & & & \\
\hline
\end{tabular}

Source: Steiner (2005, p. 10) and Muriu (2013, p. 7)

Also, Smith (2001), identified five major types of decentralization, these include: (i) deconcentration, (ii) delegation, (iii) devolution, (iv) partnership, and (v) privatisation. Ozmen (2014, pp. 416-419) has pointed out three major types of decentralization dimension. It was political, administrative and fiscal decentralization. World Bank (n.d) has divided decentralization into four types as (i) political, (ii) administrative (deconcentration, delegation, and devolution), (iii) fiscal, and (iv) economic or market (privatization and deregulation) decentralization. Moreover, the World Bank has pointed out that decentralization in political, administrative, fiscal and market decentralization can also occur in various forms and combinations across countries, as well as in countries and sectors. Cheema and Rondinelli (2007, p. 6); pointed out four types of decentralization in the governance as administrative, political, fiscal, and economic or market decentralization. In addition, Tarlton (1965, p. 865); explained another decentralization method named as asymmetrical decentralization. The theoretical and practical uses can be understood through a brief review of the dimensions of decentralization.

\section{Political Decentralization}

Political decentralization means citizens or their elected representatives are given more powers to make public decisions. Lai and Cistulli (2005, p. 4) argue that political decentralization is a process connected with the increased power of the people and the decision-making power of their representatives. It facilitates representatives representing a political system based on local electoral and pluralistic parties. This definition suggests that decision-making power, which is an integral part of the governance, is given to the sub-national level. Hossain $(2005$, p. 3) has pointed out five requirements for political decentralization as (i) constitutional reforms, (ii) 
development of pluralist political parties, (iii) strengthening of the legislatures, (iv) creations of local political units, and (v) encouraging active public interest groups. In many countries of the world, devolution of power is performed under political decentralization.

Devolution of power is an attractive and popular form of modern decentralization. Cheema and Rondinelli (1983, p. 22) have interpreted devolution of power as "Creating or strengthening independent levels or units of government through devolution of functions and authority. Through devolution, the central government relinquishes certain functions or creates new units of government that are outside of its direct control'. Similarly, Meenakshisundaram (1994, p. 11) defined devolution of power as; "the creation and strengthening of sub-national units of the government, activities of which are substantial outside the direct control of the central government". In a devolution of power, the central government abolishes some supervisory powers and delegate powers that may imply essential financial functions to the local government bodies. Many democratic countries in the world follow this system. The devolution of power aims to bring closer the citizens to the government administration mechanism and maintain a direct relationship. This invariably gives citizens opportunities to get involved in the decisionmaking process regarding administrative matters.

\section{Administrative Decentralization}

Administrative decentralization means the provision of public service obligations and power to various public institutions. These institutions must fulfil their responsibilities under the supervision of the central government. According to Work's explanation, administrative decentralization is the task of transferring government services to various levels of the government, institutions, field offices, and central government line agencies from the central government. The transfer of power, resources, and responsibilities are carried out under these circumstances. Also, administrative decentralization is common with reforms in the civil service of the states (Work, 2002). It is possible to identify administrative decentralization as a functional task of decentralization. It related to the assignment of government-wide service delivery powers, functions and responsibilities. It also transfers government servants and public affairs to its lower level of the government (Wagana, Iravo, Nzulwa, \& Kihoro, 2016b, p. 464).The administrative decentralization needs to redistribute authority, responsibility, and financial resources delivery to different levels of government agencies. It is the transfer of responsibility for the planning, financing, and management of certain public functions from the central government and its agencies to units of government agencies, subordinate units or levels of government, semi-autonomous public authorities or corporations, or to regional or functional authorities throughout the area 
(Rondinelli, 1999). There are several ways of distributing the government's administrative responsibilities. It has consisted of two main forms, namely: de-concentration and delegation.

The de-concentration is a major part of decentralizing the central government's administrative power. Under de-concentration, the administrative responsibilities of the central government are redistributed to its sub-national or local level institutions. The ministries or agency headquarters are shifting a workload to its outsiders or officials. Under these circumstances, they have been given the power to make decisions regarding administrative matters at the local level (Cheema \& Rondinelli, 1983, p. 18). Meenakshisundaram (1994, p. 11) also defined de-concentration as: "the granting of administrative authority or responsibility to the lower level ministries or agencies in a central government." Islam (2014, p. 93) equally see deconcentration as redistribution of responsibilities of power and authority among decision-makers at financial and management levels of the central government. In this way, the central government shifts the workload to lowerlevel administrations institutions. The above definitions denote that the administrative power is entrusted to local administrative institutions to carry out the functions and responsibilities the government must fulfil. Alternatively, regional administrative institutions can take administrative decisions under the central government guidelines. This means the central government can use " de-concentration method" to fulfil its responsibilities at the nearest local level.

Over the past few decades, de-concentration was the favoured method of decentralization in developing countries. Through the transfer of responsibility and financial assistance to the provincial, district or local administrative units, the central government has encouraged it, for example, Indonesia, Algeria, Thailand, Pakistan, Kenya, Tunisia, Tanzania, Philippines, Sri Lanka, and Morocco (Rondinelli \& Nellis, 1986, p. 6).

Delegation is another method used for administrative decentralization. (Rondinelli et al., 1983, p. 19) defines delegation as "it transfers managerial responsibility for specifically-defined functions to organisations that are outside the regular bureaucratic structure and that are only indirectly controlled by the central government". To Meenakshisundaram (1994, p. 11) delegation is: "transferring responsibility for specifically-defined functions to organizations that are outside the regular bureaucratic structure and are only indirectly controlled by the central government." These definitions signify that the central government transfers the authority over specific functions and responsibilities to an organization or institution to particular rules and regulations.

The central government is setting up specialized power delegation bodies and assigning responsibilities to these institutions and for example; it 
was public enterprises or corporations, housing authorities, transportation authorities, special service districts, semi-autonomous school districts, regional development corporations, or special project implementation units (World Bank, n.d). However, there is indirect control over these institutions through central government ministries. These institutions can be controlled using the administrative power of the central government. At the same time, the central government regulates these institutions through legislation and policymaking.

There are examples of service delivery using the delegation method: it was, for the management of infrastructure in East Africa, the cotton growing of Sudan and the tea growing of Kenya and the organization and management of agricultural activities; to provide social services in Latin America, Mexico's high priority development projects, and electricity management, water supply and management in Sri Lanka (Rondinelli et al., 1983, pp. 20-21). Many countries use this method of decentralization to avoid inefficiency and provide people with quality and quantitative services.

Figure 1: Forms of Decentralization
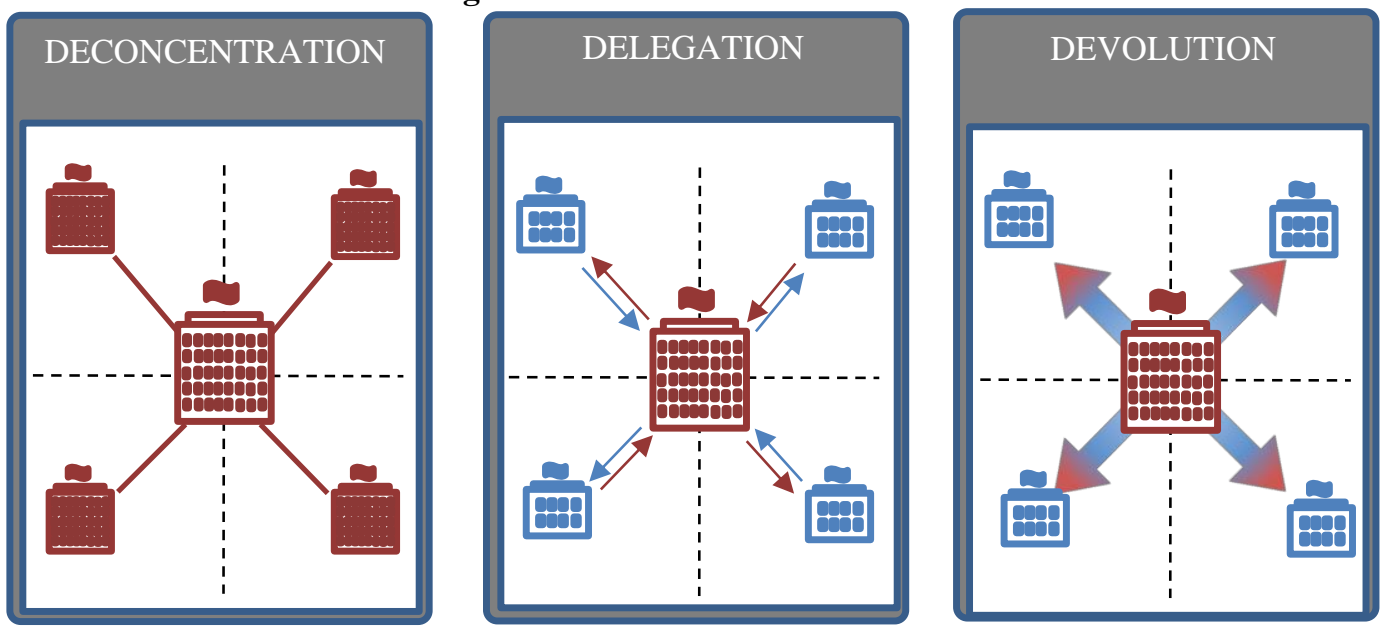

Less
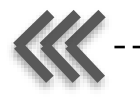

More

Decentralised

Decentralised

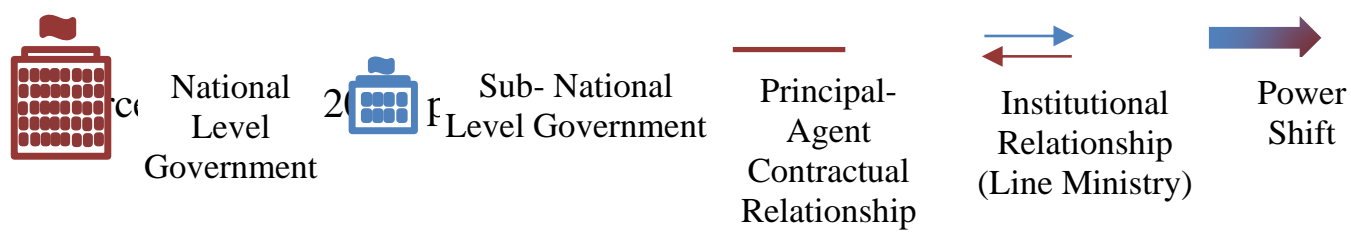


According to Figure 1, devolution is more decentralized. On the other hand, de-concentration and delegation in relative to devolution are less decentralized.

\section{Fiscal Decentralization}

Fiscal decentralization is an essential part of the world at the sub-national level, closely associated with the income and expenditure of the sub-national governments. Work $(2002$, p. 6) has defined that "fiscal decentralization means the allocation of resources to the subnational levels of the central government". Ahmad et al. (2005, p. 6) have identified four major components of fiscal decentralization: '(i) allocation of expenditure responsibilities by the central government and local layers of governments; (ii) assignment of taxes for the government layers; (iii) the design of an intergovernmental allowances system; and (iv) the formulation and monitoring of fiscal flows budgeting different government layers.' Also, many functions depend on how sub-national governments are using their expenditures and incomes of autonomy (Ganaie, Bhat, Kamaiah, \& Khan, 2018, pp. 103-104). There are two types of fiscal decentralization in terms of revenue and expenditure. It consisted of sub-national government's revenue and expenditure. The provision of sub-national government's services is highly dependent on the transfer of funds from the central government. Hence, it need to increase the revenue autonomy of sub-national governments and it is linked to the delivery of services to society (Mehmood \& Sadiq, 2010, pp. 526-527). There is a need for strong revenue sources to provide public services to sub-national level governments and require the limited expenditure of less costly activities.

\section{Market Decentralization}

Market decentralization means the formal permission of the private sector for the functions of the government. The privatisation of government institutions is done for this purpose, and this type of decentralization programmes are promoted by businesses, community groups, co-operatives, private voluntary associations, and other NGOs (Hossain, 2005, p. 5). Privatisation is one type of concept under market decentralization. Rondinelli and Iacono (1996, pp. 3-4) have defined "Privatisation is the sale of public assets to private investors. To Bach $(2000$, p. 10) privatisation is the transfer of assets in ownership, management, finance, or control to the private sector from the public sector. The broader concept of privatization involves any policy that encourages private sector participation in the provision of public services and infrastructure and eliminates or modify the monopoly state enterprises (Martin, 1997, pp. 3-4). There are success stories where high- or

middle-income countries have benefited much from privatising state assets 
and for example, improving infrastructure through private capital and providing public services, generating additional income for the government, reducing conflict between the public sector and commercial activities, increasing the efficiency of the economy, increasing market forces, expanding the economy, promoting the capital market, lack of political interference, higher microeconomic efficiency and lower borrowing requirements for the public sector (Sheshinski \& Calva, 2003, pp. 432-440). The government's role is gradually reduced as privatization is permitted.

\section{Asymmetrical Decentralization}

Asymmetric decentralization is a form of decentralization developed through the concept of decentralization to distinguish between symmetric decentralization, which affects different countries (Madubun \& Akib, 2017, p. 211). Charles Tarlton could be the first scientist who began discussing the asymmetric decentralization in 1965. In a discussion on Federalism, he explained the asymmetric decentralization (Indra, 2016) and (Tarlton, 1965). In the context of federal or other power-sharing arrangements, asymmetry implies inequality or regional or peripheral units with each other and with government at the centre. There are two asymmetric decentralization methods as political asymmetry and constitutional asymmetry. Political asymmetric decentralization creates on the impact of cultural, economic, social, and political conditions that affect different regional units. Under the asymmetric decentralization, there is no giving equivalent authoritative power to the regional units (Amarasinghe, 2011, p. 144). The asymmetric decentralization system is increasing in unitary and federal states in the globe. Examples for the unitary states are France (Corsica), Denmark (Greenland), Tanzania (Zanzibar), United Kingdom (Northern Ireland, Scotland, and Wales), Indonesia (Aceh, Papua), Philippine (Muslim Mindanao, Cordillera), China (Shenzhen, Zhuhai, Shantou, and Xiamen), Japan (Tokyo, Osaka, Nagoya, Yokohama, Kyoto and Kobe). Some examples of the Federal States are India (Assam, Meghalaya, Tripura, Mizoram, Nagaland, Jammu and Kashmir) (Tillin, 2007, pp. 52,55), Belgium, Malaysia, Spain, and Sudan (Utomo, 2009b, p. 37) (Utomo, 2009a, pp. 19-24). International attention has increased to the asymmetrical decentralization in the unitary, federal, and confederal political systems over the past decade (Watts, 2000, p. 1).

Asymmetric decentralization usually requires a more autonomy part of the country than others. In general, it means that there is a judicial power in a particular area, in another place, in a specific area of the legislature, the executive or, in some cases, the control of own people. It also has the ability to access government fiscal resources more than the rest of the country (Constitution Transformation Network and International IDEA, 2018). 
Asymmetrical decentralization helps to safeguard multiculturalism in the states and provide better services.

\section{Applicability of Decentralization to the Service Delivery}

In particular, there is a close relationship between decentralization and delivery of service. The decentralization mechanism facilitates good governance. As a result, local people are empowered. There is a need for a decentralization system for productive efficiency at the local level. Subnational governments are closer to the people. Also, sub-national governments can assist in improving the efficiency of central governments. The central government focuses on macroeconomics policies. But the sub-national governments are concerned with the microeconomics needs. It creates a good environment for providing a better service. Competition for public goods and services is enhanced through the decentralization mechanism (Ekpo, 2008, pp. 8-11). The most democratic way of providing services is political decentralization. In many countries around the world, it has become more popular. The representatives of sub-national governments are elected by the people. Therefore, people's representatives need to focus on the needs of the people. In particular, sub-national governments have a major role to play in delivering peoples' services of vital importance.

Many scholars and commentators on decentralization argue that it contributes to the improvement of governance and sub-national government service delivery in the country (Muriu, 2013, pp. 11-13). Over the past three decades, the new trend in governance has been the use of decentralization mechanisms in the provision of public services for many developed and developing countries (Shah \& Thompson, 2004, pp. 1-2). The service delivery means that the government is the institutional arrangement built up to provide its citizens with public goods and services. 'Service delivery' is identified as an essential task that shows the relationship between government and citizens. Also, a quality and reasonable service delivery is a condition that displays the good image of the government (Abe \& Monisola, 2014, p. 102). Many factors can influence the decentralized service delivery performance such as, the political framework, fiscal matters on decentralization, transparency in government actions, peoples' participation in public service delivery, the efficiency of the civil society, aspects of the social structure, the capacity of sub-national governments, and other factors (Azfar, Kähkönen, Lanyi, Meagher, \& Rutherford, 1999, p. 5). Brosio (2014) points out those even small changes in the decentralization process intensity can bring substantial gains in service delivery. Figure 2 shows the decentralization and intensity of the service delivery, presented as a, b, c, d, and e characters, while the c character indicates two different levels of decentralization with similar levels of service delivery. 
Figure 2: Relationship between the Level of Decentralization and the Level of Service Delivery

Level of service delivery

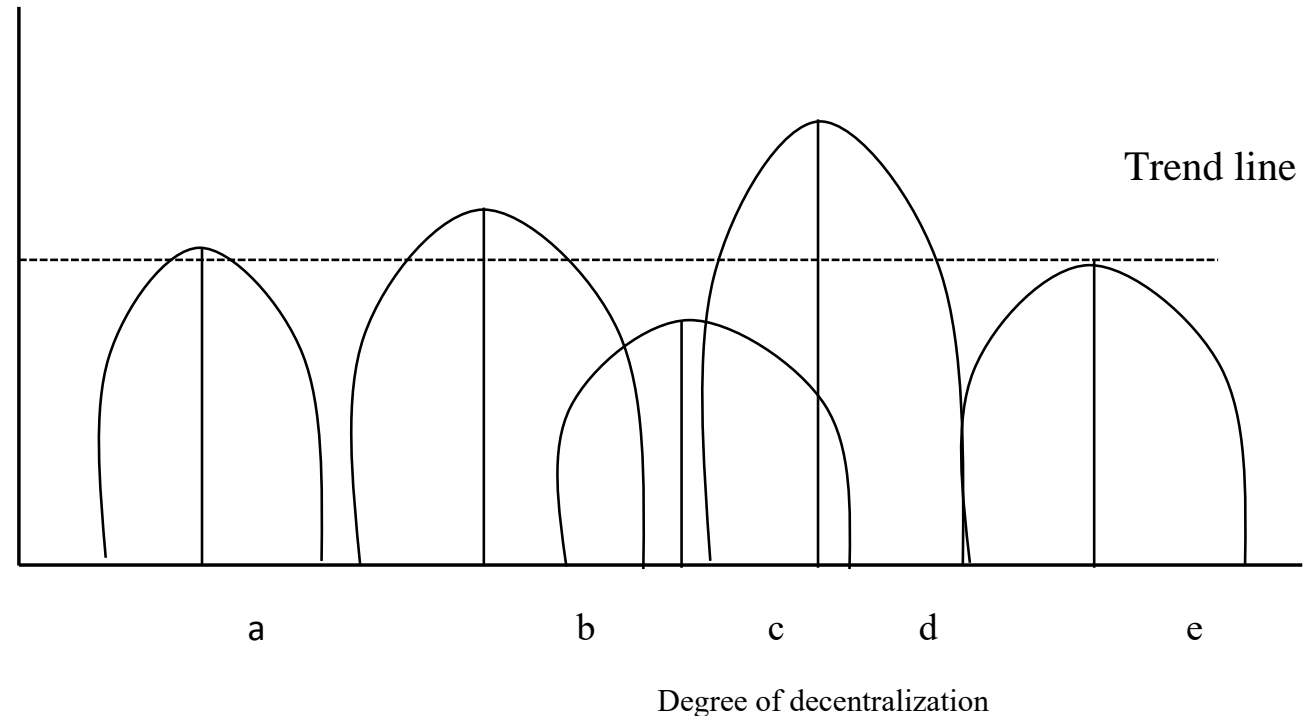

Source: (Brosio, 2014, p. 5)

The government is based on four service-delivery pillars for the fulfilment of its functions as (i) citizen satisfaction, (ii) trust, (iii) reliability, and (iv) legitimacy (Eigeman, 2007). Most developing countries have primarily decentralized the resources and responsibilities needed to provide local governments with health and education services (Khemani, 2004). However, the delivered services such as education, health care, infrastructure, social welfare, sanitation, environmental protection, and waste management happen through all these layers.

Figure 3: Relationship between Decentralization and Service Delivery

\begin{tabular}{|l|l|}
\hline Political Decentralization \\
- $\begin{array}{l}\text { Pegislative } \\
\text { Political }\end{array}$ \\
- Completion
\end{tabular}

Source;(Wagana, Iravo, \& Nzulwa, 2015, p. 464) 
As discussed by Wagana et al. (2015, pp. 463-464), a conceptual framework explains the relationship between the independent variable (political decentralization) and dependent variable (service delivery). Thus, legislative power, political competition and civil liberties are represented in political decentralization. The concept of "service delivery" has emphasized the citizens' satisfaction with the quality of services such as garbage collection and disposal, health service, rural roads, water supply, and street lighting. The conceptual model through figure 3 shows the relationship between decentralization and service delivery.

\section{Conclusion}

In general, political decentralization creates people's representatives at the sub-national level. However, administrative decentralization gives the power to provide administrative responsibilities and services to government, semi-government, or specialized agencies. Fiscal decentralization points to the sub-national level governments being granted financial power. But asymmetric decentralization on the basis of political or geographical factors gives power to the regional or sub-national level. These decentralized institutions are required to provide their services under the supervision of the central government.

In practice, many countries implement decentralization mechanism in different contexts based on various interpretations. Decentralization could be a vital strategy for the delivery of service at the sub-national level of the government. On the other hand, any level of service delivery is usually complex and this complexity must be reduced by a good understanding between service providers and recipients. This is more complicated in centralized governance but is expected to simplify service delivery in a decentralized governance structure.

Globally, many governments have introduced various types of decentralization mechanisms to improve their service delivery. In this way, most service responsibilities of the government have been provided to the lower levels. Also, specific duties and functions are assigned to public officials in the government, and some countries have assigned government responsibilities to the private sector. However, the outcome is a mixed result. The relationship between decentralization and delivery of service depends on the responsibilities of different actors in the distribution network in the government. Service delivery is of great importance in minimising the broader variation of the disparities at the sub-national level of the country.

The main objective of decentralization is to improve local service delivery. Most of the sub-national governments know more about citizen interests. Sub-national governments in Japan, for example, have a better 
understanding and concern for their citizens. Also, the Japanese sub-national government is better prepared to meet their needs.

Sub-national governments collect taxes from their citizens for their services. Taxpayers are expecting an efficient and regular service in their subnational governments. Hence sub-national governments need to be efficient in providing services. However, it is the responsibility of the sub-national governments to provide an efficient service. In addition, the central government has to provide the necessary assistance to sub-national governments in the country.

\section{Acknowledgment:}

The author would like to thanks Professor Nawalage S. Cooray at the International University of Japan for his insightful guidance.

\section{References:}

1. Abdur, R., Akram, K. A., Sher, A., Yahya, Q. G., Dilshad, A., \& Numera, A. (2017). Fiscal Decentralization and Delivery of Public Services: Evidence From Education Sector In Pakistan. Studies in Business and Economics, 12(1), p.174-184.

2. Abe, T., \& Monisola, O. J. (2014). Citizen Participation and Service Delivery at the Local Government Level: A Case of Ise/Orun Local Government in Ekiti State, Nigeria. Journal of Law, Policy and Globalization, 27, p.102-110.

3. Ahmad, J., Devarajan, S., Khemani, S., \& Shah, S. (2005). Decentralization and Service Delivery. World Bank Policy Research Working Paper(3603), p.1-27.

4. Amarasinghe, R. (2011). Asymmetrical Devolution: Understanding The Spanish Experience. In R. Amarasinghe \& J. Wickramaratne (Eds.), Power S haring The International Experience (pp. 144-167). Rajagiriya: Institute for Constitutional Studies.

5. Asfaw, A., Froherg, K., James, K. S., \& Jutting, J. (2007). Fiscal Decentralization and Infant Mortality: Empirical Evidence from Rural India. The Journal of Developing Areas, , 41(1), p.17-35.

6. Aslam, G., \& Yilmaz, S. (2011). Impact of Decentralization Reforms in Pakistan on Service Delivery-an Empirical Study. Public Administration and Development, 31(3), p. 159-171.

7. Azfar, O., Kähkönen, S., Lanyi, A., Meagher, P., \& Rutherford, D. (1999). Decentralization, Governance and Public Services the Impact of Institutional Arrangements a Review of the Literature. IRIS Center, University of Maryland, p.1-35. 
8. Bach, S. (2000). Decentralization and Privatization In Municipal Services:The Case of Health Services. Working Paper-International Labour Office(164), p.1-35.

9. Bardhan, P., \& Mookherjee, D. (2006). Decentralisation and Accountability in Infrastructure Delivery in Developing Countries. The Economic Journal, 116(508), p. 101-127.

10. Brosio, G. (2014). Decentralization and Public Service Delivery In Asia. ADB Economics Working Paper Series, p.1-54.

11. Cheema, G. S., \& Rondinelli, D. A. (1983). Implementation Decentralization Policies: An Introduction. In G. S. Cheema \& D. A. Rondinelli (Eds.), Decentralization and Development, Policy Implimentation in Developing Countries (pp. 9-34). New Delhi: Sege Publications.

12. Cheema, G. S., \& Rondinelli, D. A. (2007). From Government Decentralization to Decentralized Governance. In G. Bertucci \& M. S. Senese (Eds.), Decentrlizing Governance Emerging Concepts and Practoces (pp. 1-20). Washington,D.C: Ash Institute for Democratic Governance and Inovation.

13. Clos, J. (2015). The Challenge of Local Government Financing in Developing Countries United Nations Human Settlements Programme (UN-Habitat), the City of Barcelona and the Province of Barcelona. United Nations Human Settlements Programme, p.1-96.

14. Constitution Transformation Network and International IDEA. (2018). Asymmetric Territorial Arrangements in Decentralized Systems. Constitutional INSIGHTS, Melbourne Forum on Constitution Building, 3, p.1-8.

15. Ebel, R., \& Yilmaz, S. (2002). On the Measurement and Impact of Fiscal Decentralization. Policy Research Working Paper, p1-26.

16. Eigeman, J. (2007). Service Delivery,a Challenge for Local Governments. The Hague, the Netherlands: VNG International.

17. Ekpo, A. H. (2008). Decentralization And Service Delivery: A Framework. African Economic Research Consortium, University of Uyo,Nigeria, p.1-30.

18. Faguet, J.-P. (2014). Decentralization and Governance. World Development, 53, p.2-13.

19. Ganaie, A. A., Bhat, S. A., Kamaiah, B., \& Khan, N. A. (2018). Fiscal Decentralization and Economic Growth: Evidence from Indian States. South Asian Journal of Macroeconomics and Public Finance, 7(1), p.83-108.

20. Ghuman, B. S., \& Singh, R. (2013). Decentralization and Delivery of Public Services In Asia. Policy and Society, 32(1), p.7-21. 
21. Girishankar, N. (1998). Reforming Institutions for Service Delivery:A Framework for Development Assistance with an Application to the HNP Portfolio. Policy Research Working Papers, 2039, p.1-37.

22. Herath, T. N. (2009). Decentralization of Governance and Economic Development: the Sri Lankan Experience after Establishment of Provincial Councils. South Asia Economic Journal, 10(1), p.157-185.

23. Hossain, A. (2005). Administrative Decentralization: A Framework for Discussion and its Practices in Bangladesh. Department of Public Administration, University of Rajshahi, p.1-43.

24. Indra, K. N. (2016). The Challenge of Decentralization in Indonesia: Symmetrical and Asymmetrical Debate. International Journal of Social Science and Humanity, 6(9), p.691-697.

25. Islam, T. (2014). Decentralization and Rural Local Government In India and Bangladesh: a Brief Comparison. Journal of South Asian Studies, 2(2), p.91-106.

26. Karmel, E. (2017). Decentralising Government What You Need to Know Democacy Reporting Intrnational,Briefing Paper, 87, p. 1-13.

27. Khaleghian, P. (2003). Decentralization and Public Services: The Case of Immunization. World Bank Policy Research Working Paper, 2989, p. 1-43.

28. Khemani, S. (2004). Local Government Accountability for Service Delivery in Nigeria. Development Research Group, The World Bank, p.1-27.

29. Khemani, S. (2006). Local Government Accountability for Health Service Delivery in Nigeria. Journal of African Economies, 15(2), p.285-312.

30. Lai, K. C., \& Cistulli, V. (2005). Decentralized Development in Agriculture An Overview. EASYPol- Food and Agriculture Organization of the United Nations, 12, p.1-21.

31. Lewis, B. D. (2016). Local Government Spending and Service Delivery in Indonesia: The Perverse Effects of Substantial Fiscal Resources. Regional Studies, 51(11), p.1695-1707.

32. Madubun, J., \& Akib, H. (2017). The Prototype Model of Asymmetric Decentralization in Providing Public Services to the Island Areas. Mediterranean Journal of Social Sciences, 8(2), p.209-217.

33. Martin, B. (1997). Social and Employment Consequences of Privatization in Transition Economics: Evidence and Guidelines. The Interdependental Action Programme on Privatization, Restructuring and Economic Democracy, p.1-21.

34. Mclean, K., \& King, E. (1999). Decentralization of the Education Sector. In J. Litvack \& J. Seddon (Eds.), Decentralization Briefing Notes-WBI Working Papers (Vol. 1, pp. 51-56): World Bank Institute. 
35. Meenakshisundaram, S. S. (1994). Decentralization in Developing Countries. New Delhi: Concept Publishing Company Ltd.

36. Mehmood, R., \& Sadiq, S. (2010). Impact of Fiscal Decentralisation on Human Development: A Case Study of Pakistan. The Pakistan Development Review, 49(4), p.513-530.

37. Mugabi, E. (2005). Decentralization for Good Governance: Policies, Legal Frameworks and Implementation Strategies. In G. Bertucci (Ed.), Decentralized Governance for Democracy, Peace, Development and Effective Service Delivery (pp. 22-33). New York: UN: Division for Public Administration and Development.

38. Muriu, A. R. (2013). Decentralization, Citizen Participation and Local Public Service Delivery-A study on the Nature and Influence of Citizen Participation Ondecentralized Service Delivery In Kenya. Universität Potsdam, p.1-80.

39. OECD. (2016). Subnational Governments Around the World Structure and Finance -A First Contribution to the Global Observatory on Local Finances. Preliminary version.

40. Ozmen, A. (2014). Notes to the Concept of Decentralization. European Scientific Journal, 10(10), p.415-424.

41. Parr, S. F., \& Ponzio, R. (2002). Governance : Past, Present, Future Setting the Governance Agenda for the Millennium Declaration. Draft Paper for Fourth Global Forum, 22, p.1-12.

42. Piccone, T. (2016). Five Rising Democracies: And the Fate of the International Liberal Order. Washington, D.C: Brookings Institution Press.

43. Rao, G. (1998). India: Intergovernmental Fiscal Relations in A Planned Economy. In R. M. Bird \& F. Vaillancourt (Eds.), Fiscal Decentralization in Developing Countries (pp. 78-114). Cambridge: Cambridge University Press.

44. Rondinelli, D. (1981). Government Decentralization in Comparative Perspective: Theory and Practice in Developing Countries International Review of Administrative Sciences, 47( 2 ), p.133-145.

45. Rondinelli, D. (1999). What and Why ...What Is Decentralization. In J. Z. Litvack \& J. Seddoni (Eds.), Decentralization Briefing Notes-WBI Working Papers (pp. 1-5). Washington,D.C: World Bank Institute.

46. Rondinelli, D., \& Iacono, M. (1996). Strategic Management of Privatization: A Framework for Planning and Implementation. Public Administration \& Development, 16(3), p.247-263.

47. Rondinelli, D., \& Nellis, J. (1986). Assessing Decentralization Policies in Developing Countries: The Case for Cautious Optimism. Development Policy Review, 4(1), p.3-23. 
48. Rondinelli, D., Nellis, J., \& Cheema, S. (1983). Decentralization in Developing Countries - A Review of Recent Experience. World Bank Staff Working Papers, Management and Development Series, 8, p.199.

49. Schneider, A. (2003). Decentralization: Conceptualization and Measurement. Studies in Comparative International Development, 38(3), p.32-56.

50. Shah, A., \& Thompson, T. (2004). Implementing Decentralized Local Governance: A Treacherous Road with Potholes, Detours and Road Closures. World Bank Policy Research Working Paper, 3353, p.1-41.

51. Shen, C., Zhao, X., \& Zou, H.-f. (2014). Fiscal Decentralization and Public Services Provision in China. Annals of Economics and Finance, 15(1), p.135-160.

52. Sheshinski, E., \& Calva, L. L. (2003). Privatization and Its Benefits: Theory and Evidence. CESifo Economic Studies, 49(3), p.429-459.

53. Smith, L. D. (2001). FAO Agricultural Policy and Economic Development Series, Reform and Decentralization of Agricultural Services: A Policy Frame Work. Rome: Agriculture and Economic Development Analysis Division, Food and Agriculture Organization of the UnitedNations.

54. Steiner, S. (2005). Decentralisation and Poverty Reduction: A Conceptual Framework for the Economic Impact. Working Papers Global and Area Studies, p.1-30.

55. Tarlton, C. D. (1965). Symmetry and Asymmetry as Elements of Federalism: A Theoretical Speculation. The Journal of Politics, 27(4), p.861-874.

56. Tiebout, C. M. (1956). A Pure Theory of Local Expenditures. Jouranal of Political Economy, 64(5), p.416-424.

57. Tillin, L. (2007). United in Diversity? Asymmetry in Indian Federalism. Oxford Jounalas, Oxford University Press, 37(1), 45-67.

58. Tshukudu, T. T. (2014). Decentralization as A Strategy For Improving Service Delivery In the Botswana Public Service Sector. Journal of Public Administration and Governance, 4(2), p.40-48.

59. Uchimura, H., \& Kono, H. (2012). Intergovernmental Fiscal Relationships in Vietnam after the 2002 State Budget Law: The Center-Province and the Province-District/Commune Dimensions. In H. Uchimura (Ed.), Fiscal Decentralization and Development Experiences of Three Developing Countries in Southeast Asia (pp. 101-131). UK: Palgrave Macmillan.

60. Uchimura, H., \& Suzuki, Y. (2012). Fiscal Decentralization in the Philippines after the 1991 Code: Intergovernmental Fiscal Relationships and the Roles of Fiscal Transfers. In H. Uchimura (Ed.), 
Fiscal Decentralization and Development Experiences of Three Developing Countries in Southeast Asia (pp. 39-71). UK: Palgrave Macmillan.

61. Utomo, T. W. W. (2009a). Balancing Decentralization and Deconcentration: Emerging Need for Asymmetric Decentralization in the Unitary States. Discussion Paper, Nagoya University, Nagoya(No.74), 1-30.

62. Utomo, T. W. W. (2009b). Rethinking Decentralization and Deconcentration in the Unitary States. Graduate School of International Development (Slides of Presentation),Nagoya University, Japan, 1-63.

63. Wagana, D. M., Iravo, M. A., \& Nzulwa, J. D. (2015). Analysis of the Relationship Between Devolved Governance, Political Decentralization, and Service Delivery:A Critical Review of Literature. European Scentific Journal, 11(31), p.457-472.

64. Wagana, D. M., Iravo, M. A., Nzulwa, J. D., \& Kihoro, J. M. (2016a). Effect of Financial and Political Decentralization on Service Delivery in County Governments in Kenya. International Journal of Academic Research in Business and Social Sciences, 6(6), P.304-320.

65. Wagana, D. M., Iravo, M. A., Nzulwa, J. D., \& Kihoro, J. M. (2016b). The Moderating Effects of E-Government on the Relationship Between Administrative Decentralization and Service Delivery in County Governments in Kenya. European Scientific Journal, 12(17), p. 459-481.

66. Watts, R. L. (2000). Asymmetrical Decentralization: Functional or Dysfunctional. International Political Science Association, Canada, p.1-40.

67. Wollmann, H. (2007). Devolution of Public Tasks Between (Political) Decentralisation and (Administrative) Deconcentration - in Comparative (European) Perspective. Social Science Institute of Tokyo University, p.1-12.

68. Work, R. (2002). Overview of Decentralization Worldwide: A Stepping Stone to Improved Governance and Human Development. United Nations Development Programme, New York, p.1-20.

69. World Bank. (n.d). What is Decentralization?, The online Source Book on Decentralization and Local Development, (http://www.ciesin.org/decentralization/English/General/Different_fo rms.html): World Bank Decentralization Thematic Team. 